\title{
Penentuan Klasifikasi Tingkat Stadium Demam Berdarah Dengue (Dbd) Berdasarkan Jumlah Sel Darah Putih Berbasis Image Processing
}

\section{Determination of Classification of Stadium Dengue Fever under The Number of White Blood Cell-Based on Image Processing}

\author{
Amelia Yolanda ${ }^{1)}$ \& Rahmadi Kurnia ${ }^{2)}$ \\ ${ }^{1)}$ Jurusan Teknik Elektro Politeknik Negeri Padang Kampus Limau Manis Padang \\ Telp. 0751-72590 Fax.0751-72576 Email: meiyo81@ yahoo.co.id \\ ${ }^{2)}$ Jurusan Teknik Elektro Universitas Andalas, Kampus Limau Manis Padang \\ Email : rahmadi_kurnia@ft.unand.ac.id
}

\begin{abstract}
In medicine, knowing the number of blood cells is very important because many diseases are caused by a number of blood cells that are outside the normal condition. Blood cells can be calculated in the conventional way, but if the blood cells are counted quite a lot of takes up a lot and the results may be less accurate. In this study the authors will try to count the number of normal white blood cells to determine the level of classification stage of dengue fever based on the number of white blood cells.

This research applies some processes to be able to identify objects forming white blood cells which are leukocytes and platelets. Different template image and different processes are required in order to detect the position and the calculation of the number of objects in an image. Reverse image is in the process of look up table method to detect leukocytes, while the color conversion is a process that is applied to detect platelets.
\end{abstract}

Keywords : white blood cells, segmentation, color manipulation, reverse, image, labeling, Sweeping

\section{PENDAHULUAN}

Darah merupakan unsur dalam tubuh manusia yang memiliki peran dalam mekanisme kerja tubuh. Seluruh organ terdapat ditubuh dihubungkan oleh darah melalui pembuluh-pembuluh darah. Oleh karena itu, darah dapat menjadi cerminan keadaan tubuh, baik dalam keadaan sehat maupun sakit. Walaupun telah banyak upaya lain yang dilakukan dengan mendeteksi penyakit, misalnya dengan air ludah atau iris mata, darah masih menjadi sumber diagnosa medis yang paling dapat diandalkan. Hal ini dikarenakan banyaknya informasi penting yang dikandung oleh darah. Sebagai perbandingan, kadar zat tertentu yang terkandung di ludah hanya seperseratus sampai seperseribu dari apa yang dapat ditemukan di dalam darah (Hartadi, 2004).

Pemantauan atau diagnosis penyakit bergantung pada hasil berbagai pemeriksaan laboratorium dari contoh darah. Pemeriksaan laboratorium sebagai pemeriksaan penunjang ditambah dengan pemeriksaan klinis yang baik dan lengkap dapat membantu bila gejala klinis yang muncul kurang memadai untuk mendiagnosa penyakit. Keterlambatan diagnosis akan berakibat keterlambatan penanganan yang berpotensi meningkatkan resiko kematian. Oleh karena itu, tuntutan akan teknologi yang dapat membantu dalam pelaksanaan diagnosis medis secara cepat, mudah dan teliti semakin besar.

Jumlah sel darah \{sel darah merah (eritrosit), sel darah putih (lekosit) dan keping-keping darah (trombosit)\} sebenarnya dapat dihitung dengan cara konvensional (manual) (Hifzi, 2008). Tetapi bila sel darah yang dihitung cukup banyak akan memakan waktu. Hal ini menyebabkan perhitungan secara konvensional tidak efisien. Selain itu, perhitungan secara kovensional terhadang kurang akurat karena dilakukan dengan pengamatan langsung, hal ini disebabkan 
karena pengamatan pada sel darah sangat dipengaruhi oleh tingkat ketelitian dokter yang menganalisa. Oleh karena itu diperlukan suatu teknologi yang dapat menghitung jumlah sel darah secara cepat dan terautomatisasi sehingga mendapatkan hasil yang lebih akurat, dan bisa dilakukan melalui bantuan segmentasi citra digital.

Secara garis besar, tahapan percobaan dan simulasi yang dilakukan meliputi tahap akuisisi, tahap pengolahan dan tahap pengetesan.

Tahap akuisisi adalah tahap yang dilakukan untuk memperoleh gambar, tahap ini meliputi konfigurasi peralatan, mikroskop, webcam dan komputer, pengaktifan webcam sampai dengan pengcapture-an gambar.

Tahap pemrosesan meliputi pemprosesan awal, yaitu tahap yang dilakukan membersihkan gambar, membuang latar belakang yang tidak perlu, mengkompensasi warna dan memisahkan sel darah, sel darah putih dan keepingkeping darah. Tahap pemrosesan awal ini sangat penting dalam menentukan tingkat akurasi dari sistem, Tahap selanjutnya adalah tahap perhitungan yang merupakan lanjutan dari tahap pemrosesan awal.

Penelitian ini bertujuan untuk menghitung jumlah sel pembentukan sel darah putih normal dan sel darah putih yang terkena demam berdarah dalam suatu sampel darah, kemudian membuat program simulasi untuk menentukan klasifikasi tingkat stadium demam berdarah (DBD) berdasarkan jumlah sel darah putih yang terdapat dalam citra digital secara otomatis.

\section{METODOLOGI}

Berdasarkan tujuan dan manfaat yang ingin dicapai dari penelitian ini, yaitu melakukan penelitian terhadap kegunaan teknik segmentasi dalam penghitungan jumlah sel pembentukan darah dalam suatu citra sampel darah, dan nantinya diharapkan penelitian ini dapat bermanfaat di bidang kedokteran pada umumnya (Hifzi, 2008). Dan kalau ditinjau dari tujuan dasarnya maka penelitian ini termasuk ke dalam jenis penelitian terapan, bahwa penelitian ini merupakan pemecahan terhadap suatu masalah untuk tujuan tertentu dan merupakan aplikasi baru dari penelitian yang telah ada dengan berpedoman pada data sekunder (data dari hasil penelitian) yang relevan. Sedangkan bila ditinjau dari sifat-sifat masalahnya maka penelitian ini bersifat simulasi.

Penelitian ini dirancang agar dapat melakukan segmentasi terhadap citra sel darah, yaitu melakukan pemisahan antara objek sel darah yang satu dengan sel darah yang lainnya (antara sel darah putih normal dan sel darah putih terkena demam berdarah). Penelitian ini dimulai dengan pembacaan citra darah sebagai input. Proses dilanjutkan dengan segmentasi yaitu proses pengelompokan citra digital ke beberapa daerah atau bagian tertentu dengan tujuan untuk menyederhanakan ataupun merubah representasi gambar menjadi sesuatu yang lebih bermakna dan mudah dianalisa (R. Adollah, 2008). Metode segmentasi yang digunakan adalah segmentasi jenis Hue Saturation Lightness atau yang dikenal juga dengan Hue Saturation and Luminosity/ Luminance yaitu segmentasi berdasarkan komponen warna RGB. Proses yang dilakukan adalah memisahkan antara objek sel darah putih normal dan sel darah putih yang terinfeksi demam berdarah. Kemudian dilakukan pembuatan Pattern Warna yang akan dideteksi dan kemudian hasil dari pattern warna tersebut disimpan dalam format JPEG dan atau PNG. Proses selanjutnya adalah Colour Location yaitu proses pencarian warna yang sesuai dengan template pada citra input. Proses penghitungan jumlah pattern yang sesuai template bertujuan untuk menghitung objek dengan warna yang sesuai dengan template warna, selanjutnya akan dihitung jumlah objek sel darah putih normal dan sel darah putih normal yang terinfeksi demam berdarah yang sesuai dengan template. Proses ini akan menghasilkan jumlah lokasi warna yang sesuai dengan template. Menandai objek bertujuan untuk menandai lokasi warna yang sesuai dengan template. 
Proses ini menggunakan koordinat yang didapatkan dari proses sebelumnya.

Langkah selanjutnya adalah manipulasi warna dan pelabelan komponen (component labelling). Dengan pelabelan komponen dapat dihitung jumlah masingmasing sel darah yang ditemukan. Pelabelan komponen juga berguna untuk penyapuan terhadap noise, dan ini penting dalam analisa objek dimana objek yang memiliki jumlah piksel kurang dari jumlah piksel yang ditentukan dianggap sebagai noise dan selanjutnya dihilangkan. Khusus untuk kasus sel yang berdempet dilakukan scanning berulang sehingga didapatkan jumlah sel yang sesuai dengan jumlah sel yang sebenarnya (Hifzi, 2008).

\section{Citra}

Secara harfiah, citra (image) adalah gambar pada bidang dwimatra (dua dimensi) (Hifzi, 2008). Ditinjau dari sudut pandang matematis, citra merupakan fungsi menerus (continue) dari itensitas cahaya pada bidang dwimatra. Citra sebagai keluaran dari suatu sistem perekaman data dapat bersifat (Hifzi, 2008) :

1. Optik berupa foto.

2. Analog berupa sinyal video seperti gambar pada monitor televisi.

3. Digital yang dapat langsung disimpan pada suatu pita magnetic

\section{Pembentukan Citra}

Proses pembentukan citra dapat dilustrasikan dengan gambar berikut.

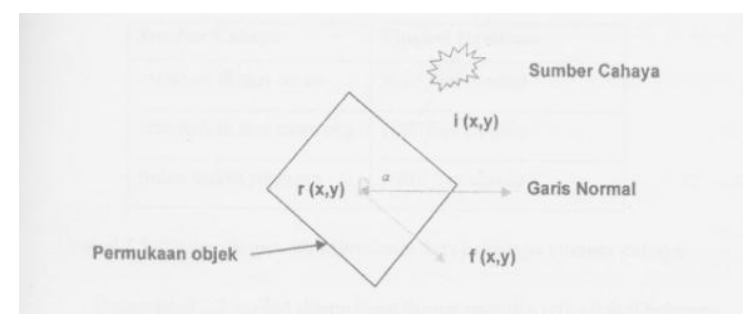

Gambar 1. Proses pembentukan citra

Sumber cahaya menyinari permukaan objek. Jumlah pancaran (iluminasi) cahaya yang diterima objek pada koordinat $(x, y)$ adalah $i(x, y)$. Objek memantulkan cahaya yang diterimanya dengan derajat pantulan $r$ $(x, y)$. Hasil kali antara $i(x, y)$ dan $r(x, y)$ menyatakan intensitas cahaya pada koordinat $(x, y)$ yang ditangkap oleh sensor visual pada sitem optik, sehingga :

$$
f(x, y)=i(x, y) \cdot r(x, y)
$$

Nilai $i(x, y)$ ditentukan oleh sumber cahaya, sedangkan $r(x, y)$, sedangkan $r(x, y)$ ditentukan oleh karakteristik objek dalam gambar. Nilai $r(x, y)=0$ mengidentifikasikan penyerapan total, sedangkan $r(x, y)=1$ menyatakan pemantulan total. Jika permukaan mempunyai derajat pemantulan nol, maka fungsi intensitas cahaya $f(x, y)$ juga nol. Sebaliknya, jika permukaan mempunyai derajat pemantulan 1, maka fungsi intensitas cahaya sama dengan iluminasi yang diterima oleh permukaan tersebut.

\section{Digitalisasi Citra}

Agar dapat diolah dengan komputer digital, maka suatu citra harus direpresentasikan secara numerik dengan nilai-nilai diskrit (Munir, 2004). Representasikan citra dari fungsi malar (kontinu) menjadi nilai-nilai diskrit disebut digitalisasi. Citra yang dihasilkan inilah yang disebut citra digital (digital image). Pada umumnya citra digital berbentuk empat persegi panjang, dan dimensi ukurannya dinyatakan sevagai tinggi $x$ lebar (atau lebar x panjang).

Citra digital yang tingginya $\mathrm{N}$, lebarnya M, dan memiliki L derajat keabuan dapat dianggap sebagai fungsi :

$$
f(x, y)\left\{\begin{array}{l}
0 \leqq \mathrm{x} \leqq M \\
0 \leqq \mathrm{y} \leqq N \\
0 \leqq \mathrm{f} \leqq L
\end{array}\right.
$$

Citra digital yang berukuran $N x M$ lazimnya dinyatakan dengan matriks yang berukuran $N$ baris dan $M$ kolom sebagai berikut :

$$
f(x, y) \approx\left[\begin{array}{cccc}
f(0,0) & f(0,1) & \ldots & f(0, M) \\
f(1,0) & f(1,1) & \ldots & f(1, M) \\
\cdot & \cdot & \ldots & . \\
f(N-1,0) & f(N-1,1) & \ldots & f(N-1, M-1)
\end{array}\right]
$$

menyatakan suatu koordinat titik pada citra, sedangkan $f(i, j)$ merukan intensits (derajat keabuan) pada titik $(i, j)$. Sebagai contoh, 
misalkan sebuah citra berukuran 256x256 piksel dan direpresentasikan secara numerik dengan matriks yang terdiri dari 256 baris (di indeks dari 0 sampai 255) dan 256 buah kolom (di-indeks dari 0 sampai 255) seperti contoh berikut :

$\left[\begin{array}{ccccc}0 & 134 & 145 & \ldots . . & 231 \\ 0 & 167 & 201 & \ldots . . & 197 \\ : & : & : & : & : \\ 221 & 219 & 210 & \ldots . . & 156\end{array}\right]$

Piksel pertama pada koordinat $(0,0)$ mempunyai nilai intensits 0 yang berarti warna piksel tersebut hitam, piksel kedua pada koordinat $(0,1)$ mempunyai intensitas 134 yang berarti warnanya antara hitam dan putih, dan seterusnya.

\section{Sel Darah Merah}

Sel darah merah (eritrosit) dibentuk dalam sumsum tulang. Sel darah merah memiliki inti sel, mitokondria atau ribosom. Eritrosit berupa cakram kecil cekung pada kedua sisinya, sehingga dilihat dari samping nampak seperti dua buah bulan sabit yang saling bertolak belakang. Kalau dilihat satu persatu warnanya kuning pucat, tetapi dalam jumlah besar terlihat berwarna merah dan memberi warna pada darah. Hemoglobin merupakan zat padat dalam eritrosit yang menyebabkan warna merah. Sel ini tidak dapat melakukan mitosis, fosforilasi, oksidatif sel atau pembentukan protein. Eritrosit berfungsi sebagai transfor atau pertukaran oksigen $\left(\mathrm{O}_{2}\right)$ dan karbondioksida (CO2) (Hartadi, 2004).

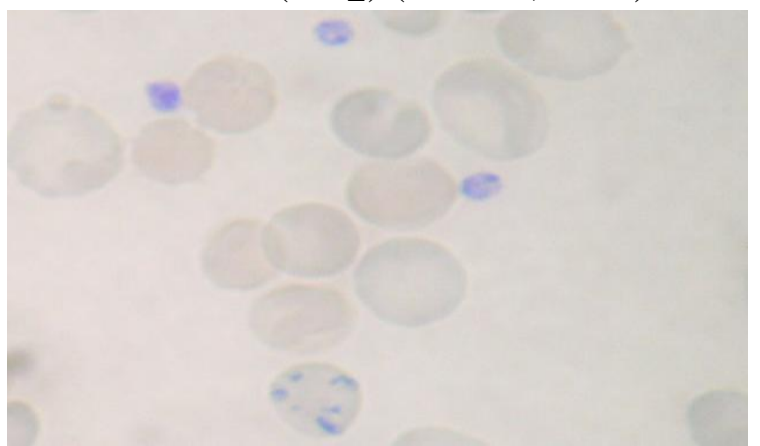

Gambar 2. Citra Sel Darah Merah
Jumlah sel darah merah yang normal adalah :

Laki-laki : $4.500 .000-6.000 .000 \mathrm{sel} / \mathrm{mm}^{3}$ Perempuan: $4.000 .000-5.500 .000 \mathrm{sel} / \mathrm{mm}^{3}$ Bayi $\quad: 5.000 .000-7.000 .000 \mathrm{sel} / \mathrm{mm}^{3}$

\section{Sel Darah Putih}

Seperti eritrosit, leukosit juga diproduksi dalam sumsum tulang. Jenisjenis golongan dari sel ini adalah golongan yang tidak bergranula (agranulosit) yaitu limfosit $\mathrm{T}$ dan $\mathrm{B}$, monosit dan makrofag, serta golongan yang bergranula (granulosit) yaitu eosinfil, basofil, dan neutrofil. Jumlah sel darah putih dalam darah yang normal adalah sekitar 5.000$10.000 \mathrm{sel} / \mathrm{mm}^{3}$. Peran sel-sel darah putih ialah untuk mengenali dan melawan mikroorganisme pada reaksi imun dan untuk membantu proses peradangan dan penyembuhan. Leukosit berbeda dengan eritrosit, karena tidak mengandung hemoglobin dan dapat keluar dari sistem sirkulasi dan mencapai bagian-bagian jaringan, sesuai fungsinya untuk melawan penyaki (Hartadi, 2004).

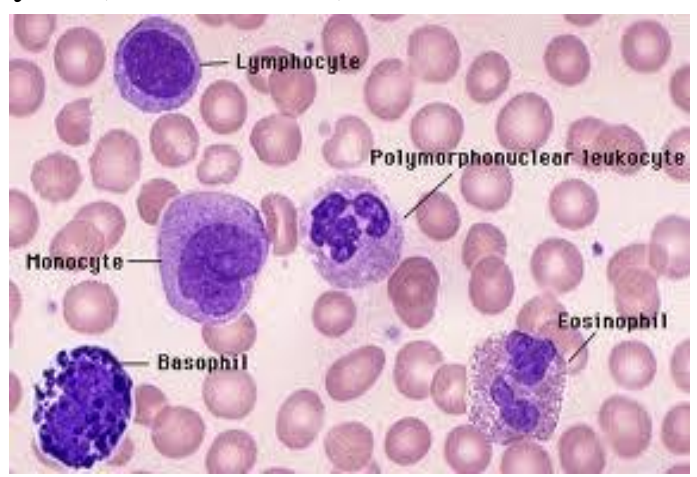

Gambar 3. Sel Darah Putih Normal

Sel darah putih dapat dihitung sebagai suatu kelompok (hitung sel darah putih). Jika diperlukan keterangan yang lebih terperinci, bisa dilakuan penhitungan jenisjenis tertentu dari sel drah putih (differntial white blood cell count) : yaitu

1. Neutrofil

2. Eusinofil

3. Basofil

4. Limfosil

5. Monosit 


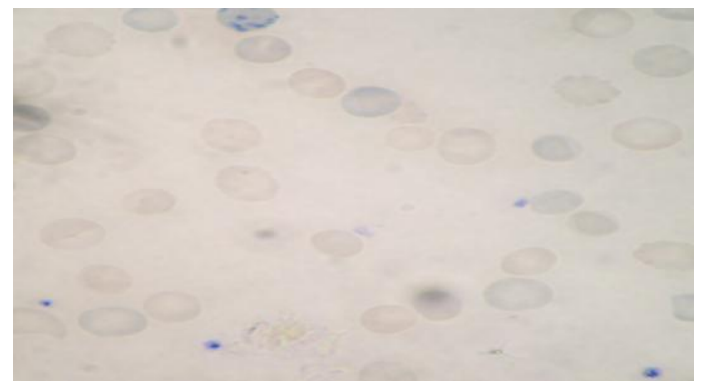

Gambar 4. Sel darah terindikasi DBD

\section{Keping Darah (Trombosit)}

Keping darah atau trombosit adalah sel anuclear nulliploid (tidak mempunyai nukleus) dengan bentuk tak beraturan dengan ukuran diameter 2-3 $\mu \mathrm{m}$ yang merupakan fragmentasi dari megakariosit. Trombosit tersirkulasi dalam darah dan terlibat dalam mekanisme hemostatis tingkat sel dalam proses pembekuan dengan membentuk darah beku. Nilai normal jumlah trombosit berkisar antara 200.000-300.000 sel $/ \mathrm{mm}^{3}$, nilai dibawah rentang tersebut dapat menyebabkan pendarahan, sedangkan nilai di atas rentang yang sama dapat meningkatkan risiko trombosis. Trombosis memiliki bentuk yang tidak teratur, tidak berwarna, tidak berinti, berukuran lebih kecil dari eritrosit dan leukosit, dan mudah pecah bila tersentuh benda kasar (Hifzi, 2008).

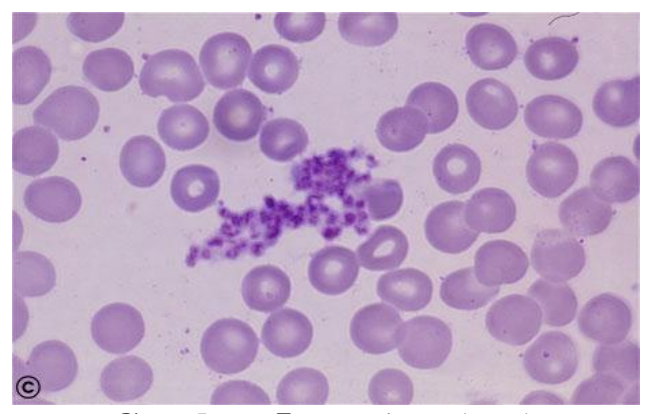

Gambar 5. Keping darah

\section{Demam Berdarah}

Deman berdarah Dengue (DBD) adalah penyakit virus yang sangat berbahaya karena dapat menyebabkan penderita meninggal dunia dalam waktu yang sangat pendek (beberapa hari) (Hifzi,
2008). Demam Berdarah Dengue (DBD) merupakan penyakit infeksi yang berakibat fatal dalam waktu yang relatif singkat. Penyakit ini tergolong sulit dibedakan dari penyakit demam berdarah yang lain. Hal ini disebabkan karena infeksi virus dengue yang menyebabkan DBD bisa bersifat asimtomatik atau tidak jelas gejalanya. Penyakit Deman Berdarah Dengue (DBD) menyerang semua umur dewasa maupun anak-anak. Dan penyakit ini termasuk ke dalam sepuluh penyebab perawatan di rumah sakit dan kematian pada anak- anak.

Penyakit ini masuk ke Indonesia sejak tahun 1968 melalui pelabuhan Surabaya, dan pada tahun 1980 DBD telah dilaporkan melanda seluruh provinsi di Indonesia (Hifzi, 2008).

Jumlah kasus demam berdarah di Indonesia tercatat masih tinggi, bahkan paling tinggi dibanding negara lain di ASEAN. Data Kementrian Kesehatan (Kemenkes) RI mencatat jumlah kasus Demam Berdarah Dengue (DBD) pada tahun 2010 mencapai sekitar 150.000. Angka ini cenderung stabil pada tahun 2011, sehingga kasus DBD di Indonesia belum bisa dikatakan berkurang.

\section{Segmentasi Citra}

Segmentasi citra merupaqkan salah satu proses pengolahan citra tingkat dasar. Karena hanya dilakukann proses analisa citra untuk kemudian mengubah tampilan citra secara keseluruhan, mengeluarkan informasi yang tidak diperlukan dan meningkatkan informasi yang dibutuhkan untuk proses pengolahan citra pada tingkat selanjutnya.

Segmentasi merupakan proses pemisahan (separation) terhadap daerah atau bagian - bagian tertentu pada citra, dimana bagian - bagian tersebut memiliki homogenitas dalam beberapa segi utama, diantaranya tekstur, warna dan intensitas. Bagian-bagian tersebut bersifat unik, jadi berbeda dengan bagian homogen yang lain. Selanjutnya dari bagian - bagian ini bisa ditemukan korelasi atau kaitan dengan 
objek yang nyata atau sebenarnya (realword) (Pratt, 2001).

\section{Sampel yang Diteliti}

Terdapat tiga sampel sel darah yang diuji dalam penelitian ini. Sampel sel darah tersebut terdiri dari sampel sel darah normal, sel darah pasien dewasa yang terindikasi demam berdarah dan sampel darah pasien anak yang juga terindikasi demam berdarah.

Table berikut ini adalah citra sample yang digunakan pada penelitian ini.

Tabel 1. Sampel sel darah

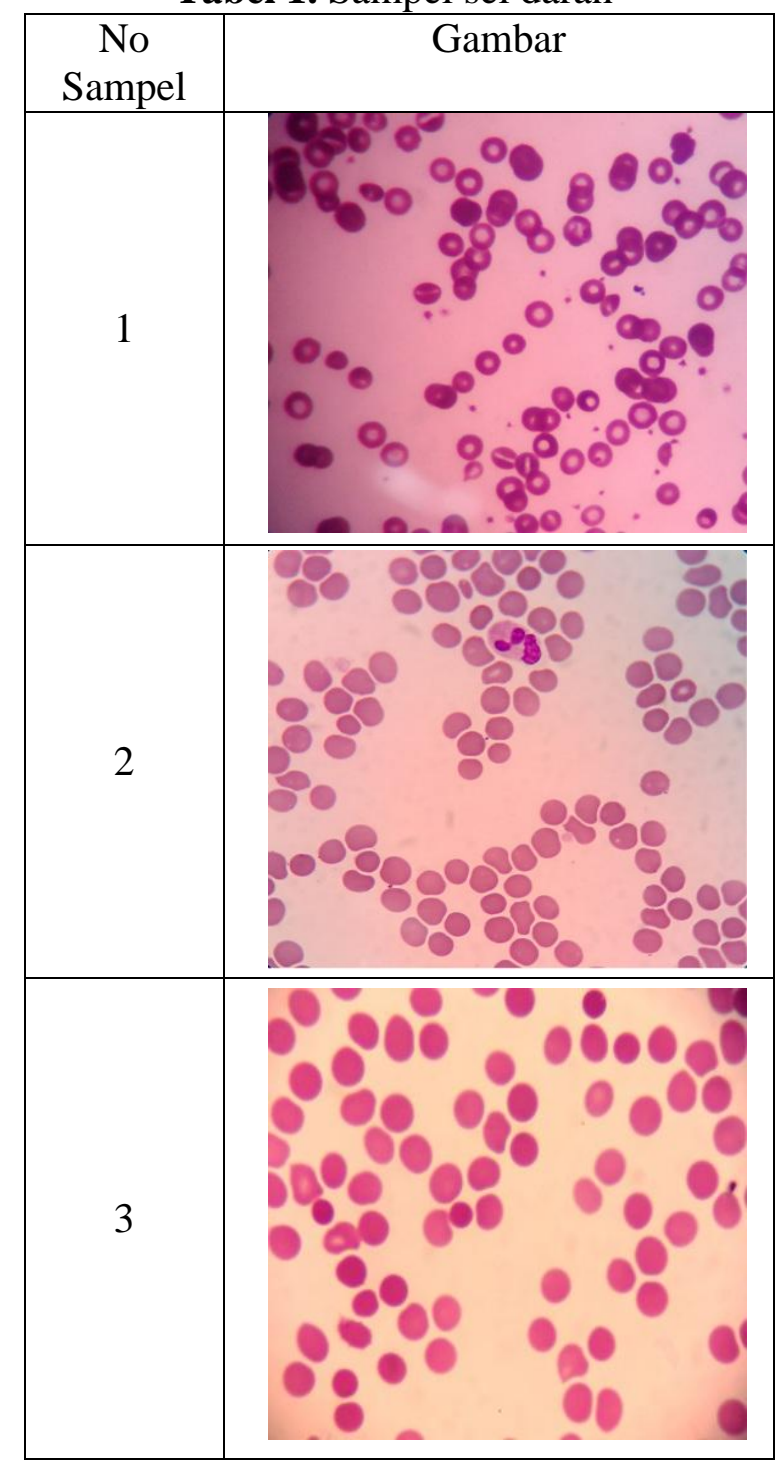

\section{Prosedur Penelitian}

Dilakukan untuk mendapatkan pemahaman tentang konsep-konsep teoritis yang berhubungan dengan judul penelitian.
Studi literatur berupa diskusi dengan pembimbing, mengambil referensi dari internet dan buku-buku panduan, Studi literatur juga dilakukan terhadap aplikasi LabVIEW yang dalam penelitian ini menjadi sarana aplikatif.

\section{Penyusunan Algoritma Program}

Program yang dirancang dalam penelitian ini terbagi atas 3 (tiga) algoritma pokok, adalah :

a. Algoritma segmentasi citra berdasarkan metode Hue Saturation Lightness. Pertama-tama dibuat algoritma untuk segmentasi citra dan dilanjutkan dengan algoritma untuk memisahkan antara objek sel darah putih normal dengan sel darah putih yang terinfeksi demam berdarah.

b. Algoritma manipulasi warna, untuk memudahkan dalam proses pelabelan objek maka masing-masing objek yang telah disegmen diberi warna yang sama.

c. Algoritma pelabelan objek. Masingmasing objek yang telah dimanipulasi diberi label yang berbeda yang bertujuan untuk menghitung jumlah masingmasing objek sel darah putih normal dengan sel darah putih terkena demam berdarah.

\section{Pembuatan Program}

Berdasarkan algoritma yang telah ditentukan diatas, dibuat program pengolahan citra penghitungan jumlah sel darah (Blood Cells Count) dengan menggunakan bahasa pemograman LabVIEW.

\section{Pengujian Terhadap Hasil Pengolahan Citra}

Pengujian dilakukan dengan cara membandingkan citra atau image yang di gunakan sebagai sumber input dan citra hasil pengolahan dengan menggunakan LabVIEW untuk mendapatkan posisi pelabelan objek dan hasil penghitungannya melalui simulasi program. 


\section{Analisa Keluaran Sistem}

Analisa keluaran sistem didasarkan pada teknik analisa sistem yang telah dijabarkan pada subbab 3.4. Keluaran dari sistem ini adalah berupa visualisasi citra hasil pengolahan dan menghitung jumlah sel objek yang ditemukan. Visualisasi citra berupa citra hasil pengolahan segmentasi $H S L$ dimana citra asli yang mengandung sel darah putih normal dan sel darah putih yang terkena demam berdarah setelah dilakukan segmentasi dan manipulasi warna masingmasing sel tersebut tersebut terpisah, jadi citra yang dikeluarkan adalah citra yang mengandung sel darah putih normal dan sel darah putih yang terinfeksi demam berdarah saja (Hifzi, 2008).

\section{Teknik Analisa Sistem}

1. Analisa visual citra (manual)

Dilakukan dengan menghitung secara manual jumlah masing-masing sel darah putih normal dan sel darah putih terinfeksi demam berdarah dalam citra sampel darah dan membandingkan dengan hasil yang didapat melalui simulasi program.

2. Analisa perhitungan otomatis (melalui simulasi program)

Dilakukan dengan cara menghitung jumlah sel-sel darah putih dalam suatu citra sampel dengan metode segmentasi yang terintegrasi dalam simulasi program.

\section{Perancangan Sistem}

Terdapat dua flowchart untuk membangun sistem ini. Flowchart yang pertama merupakan flowchart proses perancangan template sistem dan flowchart yang kedua merupakan flowchart untuk identifikasi dan penghitungan objek berdasarkan template yang dirancang.

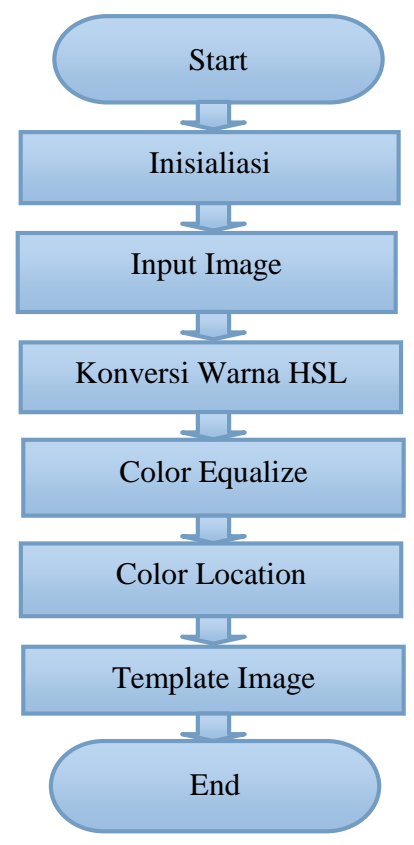

Gambar 6. Flowchart pembuatan template.

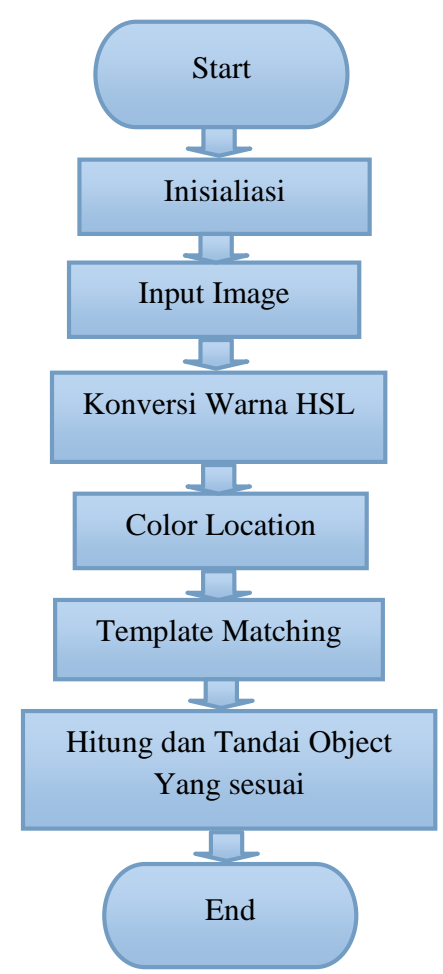

Gambar 7. Flowchart identifikasi objek

\section{Analisa Kinerja Sistem}

Sistem ini secara umum dirancang agar dapat melakukan segmentasi pada citra sel darah putih normal dan sel darah putih yang terinfeksi demam berdarah. Selanjutnya penghitungan jumlah masing-masing sel pembentukan darah (sel darah putih normal 
dan sel darah putih yang terinfeksi demam berdarah).

Secara garis besar, sistem yang dirancang dalam penelitian ini dibagi menjadi dua tahapan proses yaitu tahapan untuk pembuatan template dan tahapan identifikasi kesesuaian objek dengan template. Untuk proses pertama sampai dengan ketiga, kedua proses memiliki kesamaan aksi, lebih lengkapnya diuraikan sebagai berikut :

\section{Loading image input}

Loading Image adalah proses awal dari sistem untuk memilih citra atau image yang akan diproses. Sebelum di gunakan sebagai sumber atau input ke sistem, citra atau image telah diketahui ukuran perbesaran mikroskopnya dan telah disimpan di folder yang sama dengan program. Untuk mendapatkan citra atau image yang ideal, semua sample harus memiliki ukuran perbesaran mikroskop dan pencahayaan yang sama.

\section{Proses Segmentasi.}

Metode segmentasi yang digunakan adalah metode segmentasi HSL. Dalam hal ini digunakan HSL untuk meningkatkan intensitas warna sel darah merah. Setelah proses ini maka komponen warna $\mathrm{R}$ dan $\mathrm{G}$ umumnya akan bernilai 0 .

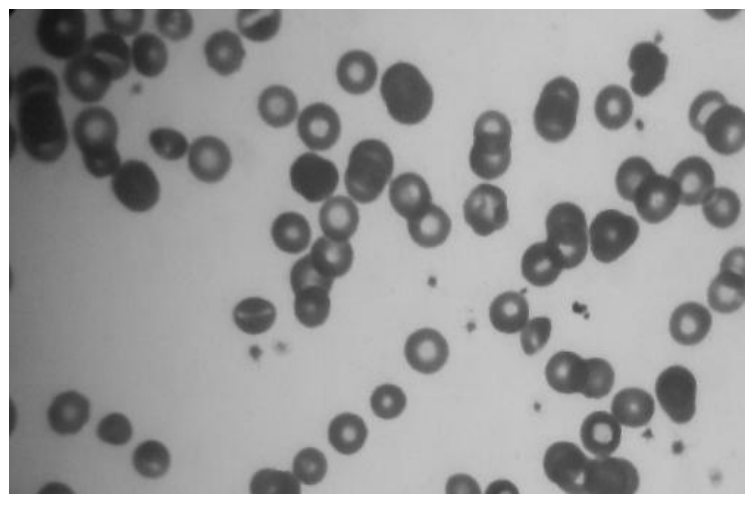

Gambar 8. Citra Hasil Segmentasi Sample 1

\section{Konversi Warna.}

Proses konversi warna di fungsikan untuk meningkatkan contrast image atau menambah tingkat kejelasan diantara image atau citra yang telah disegmentasi tersebut. Komponen yang digunakan adalah IMAQ ColorEqualize. Output konversi warna ini adalah RGB, HSL. Sedangkan output yang kedua adalah Luminance (LUMA). Tujuan dari proses ini adalah untuk menambah tingkat kejelasan masing - masing warna yang ada pada image atau citra. Sehingga dapat dideteksi batas antara masing - masing warna tersebut.

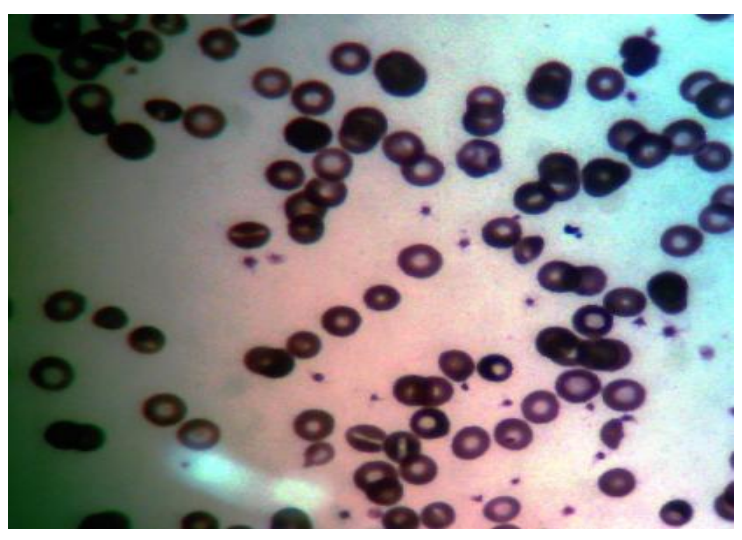

Gambar 9. Citra hasil konversi warna sampel 1

\section{Manipulasi Warna.}

Proses manipulasi warna yang dimaksudkan disini adalah, dengan membalikkan warna. Proses ini menggunakan metode LookUp Table. Didalam LookUp Table terdapat bermacam proses. Proses yang digunakan pada sistem ini adalah proses reverse. Proses reverse dipilih karena meniadakan rekayasa (customization) image atau citra, sehingga menjamin citra atau image yang digunakan bersih dan tetap pada kondisi aslinya. 


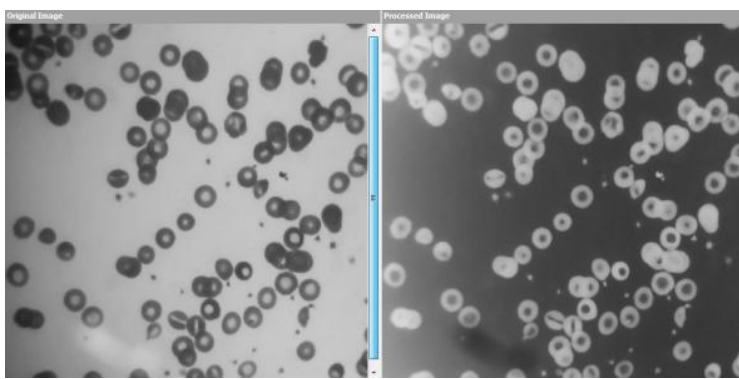

Gambar 10. Citra hasil manipulasi sampel 1

\section{Colour Equalize.}

Proses ini merupakan proses lanjutan dari proses konversi warna. Proses ini masih menggunakan komponen IMAQ ColorEqualize. Proses ini hanya dilakukan pada tahapan pembuatan template sedangkan tahapan identifikasi tidak melakukan proses Colour Equalize. Hal ini bertujuan untuk tetap menjaga keutuhan warna yang sudah dikonversi melalui proses manipulasi warna.

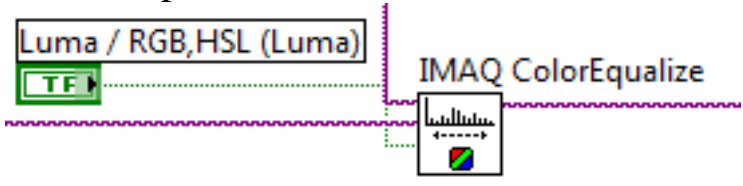

Gambar 11. Blok diagram equalize image

\section{Colour location.}

Proses ini berfungsi untuk mencari warna yang sesuai dengan template pada source image. Proses ini dilakukan oleh ColorLocation.vi. Kedua tahapan baik pembuatan template maupun identifikasi objek melakukan tahapan ini.

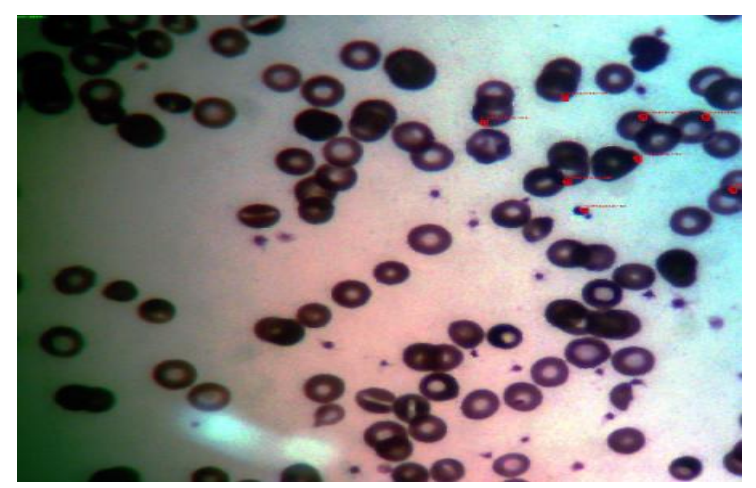

Gambar 12. Color Location

\section{Pembuatan template image.}

Proses ini merupakan pembuatan template warna yang akan di deteksi. Dan hasil template tersebut di simpat dalam format JPEG. Proses ini dilakukan dalam Visual Express Visual Assistant. Proses ini hanya dilakukan pada tahapan pembuatan template image. Tahapan pembuatan template selesai sampai disini. Adapun Template image yang dirancang dan digunakan pada sistem ini adalah sebagai berikut :

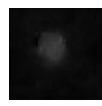

Gambar 13. Template leukosit

Gambar 14. Template trombosit

\section{Hitung objek yang sesuai template.}

Sistem akan menghitung objek dengan warna yang sesuai dengan template warna. Selanjutnya akan dihitung jumlah objek yang sesuai dengan template. Proses ini akan menghasilkan juga lokasi warna yang sesuai dengan template.

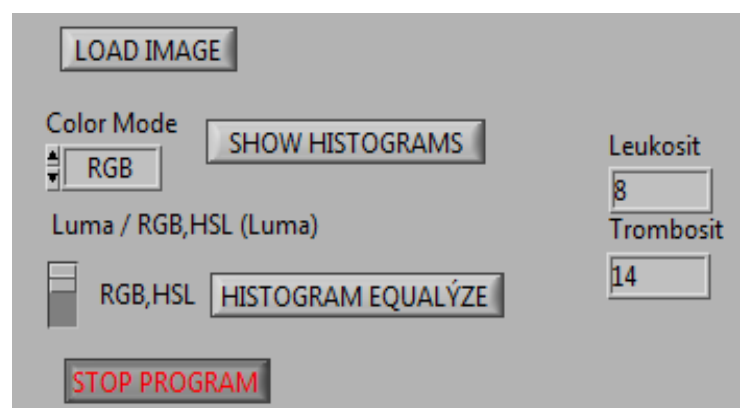

Gambar 15. Hasil perhitungan Program

\section{Tandai object}

Proses ini berfungsi untuk menandai lokasi warna yang sesuai dengan template. Proses ini menggunakan koordinat yang didapatkan dari proses sebelumnya. Setelah itu akan di gunakan persegi panjang untuk menandai objek tersebut. 


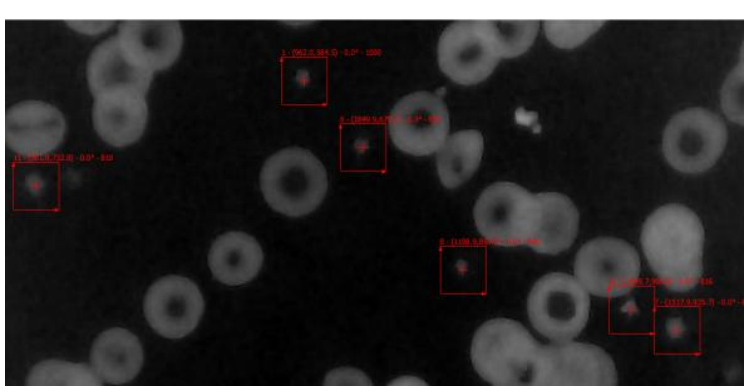

Gambar 16. Tandai Objek
10. Hasil.

Hasil akhir dari proses yang dilalui sistem ini adalah berupa citra atau image yang menghitung dan menandai posisi dari sel darah yang terindikasi demam berdarah.

Tabel 2. Posisi dan jumlah leukosit pada sampel 1

\begin{tabular}{l|ll|l|l|l|l|l|l|l|l|l|l}
\hline Results... & 1 & 2 & 3 & 4 & 5 & 6 & 7 & 8 & & \\
\hline \hline Center X & 1299,00000 & 1638,00000 & 1071,00000 & 1433,00000 & 1578,00000 & 1261,00000 & 1421,00000 & 1256,00000 & & \\
\hline Center Y & 633,00000 & 567,00000 & 350,00000 & 332,00000 & 333,00000 & 542,00000 & 466,00000 & 270,00000 & & \\
\hline Score & 851 & 811 & 810 & 808 & 806 & 800 & 799 & 789 & & \\
\hline & & & & & & & & & & \\
\hline
\end{tabular}

Tabel 3. Posisi dan jumlah trombosit pada sampel 1

\begin{tabular}{|c|c|c|c|c|c|c|c|c|c|c|c|c|}
\hline Results.... & 1 & 2 & 3 & 4 & 5 & 6 & 7 & 8 & 9 & 10 & 11 & 12 \\
\hline XPosition & 962,00000 & 1287,91675 & 777,96161 & 717.83435 & 1360,85962 & 1049,92651 & 1517,88904 & 1198,90955 & 1430,89526 & 1147,98242 & 561.84045 & 1449.73706 \\
\hline Y Position & 584,50000 & 1460,60059 & 1472,67102 & 1070.58118 & 1299,91589 & 678,95087 & 935.65967 & 850.53094 & 250,73175 & 1144,98254 & 732,81305 & 906,75952 \\
\hline Angle & 0.000000 & 0,000000 & 0,000000 & 0,000000 & 0,000000 & 0,000000 & 0,000000 & 0,000000 & 0,000000 & 0,000000 & 0,000000 & 0,000000 \\
\hline Score & 1000,00000 & 884,64777 & 883.16388 & 869.42505 & 858.99005 & 857,89844 & 846,59772 & 846.16931 & 839.43127 & 828,30206 & 817,56226 & 815,78729 \\
\hline
\end{tabular}

\section{HASIL DAN PEMBAHASAN}

Sesuai dengan tujuan penelitian ini, maka hasil perhitungan secara otomatis dan perhitungan secara manual dituangkan dalam bentuk tabel berikut ini. Berdasarkan tabel tersebut diharapkan dapat ditentukan tingkat stadium demam berdarah.

Tabel 4. Perbandingan perhitungan manual dan otomatis

\begin{tabular}{|c|c|l|c|c|}
\hline \multirow{2}{*}{ No } & \multirow{2}{*}{$\begin{array}{c}\text { Citra } \\
\text { Sampel }\end{array}$} & \multirow{2}{*}{$\begin{array}{c}\text { Jenis Sel } \\
\text { Darah }\end{array}$} & & \multicolumn{2}{|c|}{$\begin{array}{c}\text { Penghitungan jumlah Sel } \\
\text { Darah }\end{array}$} \\
\cline { 4 - 5 } & & & Manual & Otomatis \\
\hline \multirow{2}{*}{1} & \multirow{2}{*}{ Sampel 1 } & Leukosit & 2 & 8 \\
& & Trombosit & 14 & 14 \\
\hline \multirow{2}{*}{2} & \multirow{2}{*}{ Sampel 2 } & Leukosit & 15 & 16 \\
& & Trombosit & 2 & 2 \\
\hline \multirow{2}{*}{3} & \multirow{2}{*}{ Sampel 3 } & Leukosit & 5 & 6 \\
& & Trombosit & 2 & 1 \\
\hline
\end{tabular}

Dari hasil perhitungan secara manual dan otomatis (sistem) ditemukan perbedaan hasil. Hal ini disebabkan karena pada perhitungan manual hanya mengandalkan kemampuan visual dari pengamat untuk mengamati image yang digunakan pada sistem ini dalam menghitung jumlah leukosit maupun trombosit. Sedangkan untuk perhitungan otomatis, sistem mampu menghitung objek yang tergolong ke leukosit maupun trombosit. 


\section{SIMPULAN}

1. Untuk pendeteksian objek yang berbeda pada satu citra atau image diperlukan lebih template yang berbeda pula untuk menjamin keakuratan hasil pendeteksian objek.

2. Terdapat perbedaan proses yang dilakukan oleh sistem untuk mendeteksi objek leukosit dan trombosit. Objek leukosit dideteksi setelah dilakukan metode look up table dengan proses reverse image, sedangkan objek trombosit dideteksi setelah dilakukan proses konversi warna yang dilengkapi dengan proses equalize image.

3. Sistem yang dirancang mampu memproses citra atau image sampel darah untuk melakukan proses perhitungan sel pembentuk darah putih yaitu leukosit dan trombosit.

4. Hasil perhitungan objek pembentuk sel darah putih pada sistem dengan perhitungan manual menunjukkan perbedaan. Hal ini disebabkan karena pada perhitungan manual hanya mengandalkan kemampuan visual dari pengamat. Sedangkan perhitungan dari sistem dilakukan secara otomatis menggunakan sistem yang dirancang menggunakan LabVIEW.

5. Diperlukan tahapan lebih lanjut oleh dokter atau pihak yang kompeten dalam menentukan klasifikasi stadium demam berdarah pasien yang terindikasi mengidap demam berdarah.

\section{DAFTAR PUSTAKA}

Hartadi Diaz, Sumardi, Isnanto Rizal, R, 2004, Simulasi Penghitung Jumlah Sel Darah Merah, Jurusan Teknik Elektro UNDIP.Anggraeni Arie, Putra Darma, 2010, Sistem Pengenalan Kondisi Sel Darah Merah (ERYTHROCYTE) Pada Citra Mikrospis, Program Studi Teknologi Informasi Fakultas Teknik, Unibersitas Udayana, Bali.

Hidayatno, Achmad, dkk. 2006. Penentuan wilayah wajah manusia pada citra berwarna berdasarkan warna kulit dengan metode template maching. Semarang. Universitas Diponegoro

Hifzi Al, 2008. Simulasi Penghitungan Jumlah Sel Pembentukan Darah Menggunakan Teknik Segmentasi Amplitudo, Program Studi Teknik Telekomunikasi, Universitas Andalas, Padang.

http://www.goegle.co.id/esmartschool.html. "Fungsi darah" . Diakses tanggal 24 Januari 2013

Munir Rinaldi. 2004. Pengolahan Citra Digital dengan Pendekatan Algoritmik. Informatika Bandung

Munir Rinaldi. 1992. Pengantar Pengolahan Citra. Elex Media Komputindo.

Pratt, William K. 2001. Digital Image Processing, $3^{\text {rd }} \boldsymbol{E} \boldsymbol{d}$. New York. John Wiley \& Sons.

R. Adollah, M.Y. Mashor, N.F. Mohd Nasir, H. Rosline, H. Mahsin, H. Adilah, 2008, "Blood Cell Image Segmentation: A Review", Biomed, Proceedings 21, pp. 141-144, 2008 